\title{
Preoperative Anemia Is A Predictor of Cacoethic Postoperative Outcomes Following Open Pancreatoduodenectomy - A Propensity Score-Based Analysis
}

Jing-Yong $X u$

Beijing Hospital

Xiao-Dong Tian

Peking University First Hospital

Yin-Mo Yang

Peking University First Hospital

Jinghai Song ( $\square$ songjinghaisci@163.com )

Beijing Hospital

Jun-Min Wei

Beijing Hospital

Research

Keywords: anaemia, complication, mortality, pancreaticoduodenectomy, propensity score matching

Posted Date: August 18th, 2021

DOI: https://doi.org/10.21203/rs.3.rs-783466/v1

License: @ (i) This work is licensed under a Creative Commons Attribution 4.0 International License. Read Full License 


\section{Abstract}

Background: Preoperative anaemia is a common clinical situation that was proved to be associated with severe outcomes in major surgery but not pancreatic surgery alone. We aimed to study the impact of preoperative anaemia on morbidity and mortality in patients undergoing open pancreaticoduodenectomy by using propensity score matching (PSM) to balance the basal data and reduce bias.

Methods: Consecutive patients undergoing open pancreaticoduodenectomy with complete record of preoperative haemoglobin at two pancreatic centers in China between 2015 to 2019 were analysed. Haemoglobin less than $12 \mathrm{~g} / \mathrm{dl}$ for male and $11 \mathrm{~g} / \mathrm{dl}$ for female were defined as anaemia in Chinese population. Clinical and economic outcomes were compared before and after propensity score matching (PSM). Logistic regression analysis was used to assess correlation between variables and anaemia.

Results: The unmatched initial cohort consist of 517 patients. 148 cases $(28.6 \%)$ were diagnosed as anaemia at admission, and no case received preoperative blood transfusion or anti-anaemia therapy. After PSM, 126 cases were in each group. The rate of severe postoperative complications was significantly higher in anaemia group than in normal group ( $43.7 \%$ versus $27.0 \%, P=0.006)$, among which prevalence of clinically relevant postoperative pancreatic fistula ( $31.0 \%$ versus $15.9 \%, \mathrm{P}=0.005)$ and cardiac and cerebrovascular events $(4.0 \%$ versus $0.0 \%, P=0.024)$ were most significant. It costed more in the anaemia group $(26958.2 \pm 21671.9$ versus 20987.7 \pm 10237.9 USD, $P=0.013$ ). Among all patients, multivariate analysis showed that preoperative obstructive jaundice [OR $1.813,95 \% \mathrm{Cl}(1.206-2.725), \mathrm{P}=0.004$ ] and pancreatic ductal adenocarcinoma [OR $1.861,95 \% \mathrm{Cl}(1.178-2.939), \mathrm{P}=0.008]$ were predictors of anaemia. Among paired patients, preoperative anaemia [OR 2.593, 95\% $\mathrm{Cl}(1.481-5.541), \mathrm{P}=0.001$ ] and malignant pathology [OR 4.266, 95\% $\mathrm{Cl}(1.597-11.395)$, $\mathrm{P}=0.004]$ were predictors of postoperative severe complications.

Conclusions: Preoperative anaemia is a predictor of cacoethic postoperative outcomes following open pancreatoduodenectomy and needs identified and treated.

\section{Introduction}

Preoperative anaemia is a common clinical situation, ranging from $25-40 \%$ in large observational studies [1, 2]. Many studies have proved the association between preoperative anaemia and postoperative mortality, morbidity and prolonged length of hospital stay $[3,4]$. What's more, preoperative anaemia may also increase the rate of perioperative blood transfusion, which has been reported to be a risk factor of worse postoperative outcomes [5]. Since there has been a long tradition that anaemia can be corrected easily with transfusion, the treatment of preoperative anaemia was still ignored and controversial to a certain extent [6].

Pancreatoduodenectomy is one of the major abdominal operations associating with high postoperative mortality and morbidity. There are many risk factors throughout the whole perioperative procedure [7]. Although preoperative anaemia was proved to be risk factor in many retrospective studies in cardiac and noncardiac surgeries, the actual role that it plays in pancreatic surgery is still unclear. In this study, we aimed to reveal the association between preoperative anaemia and adverse outcomes in pancreatoduodenectomy using propensity score matching to balance the relative factors and reduce bias between anaemia and no anaemia groups. 


\section{Materials And Methods}

\section{Patients and Baseline Characteristics}

Data of consecutive patients with complete records of preoperative haemoglobin were analysed retrospectively. All patients were received open PD at two university hospitals in China between May 2015 and May 2019. Figure 1 showed the flowchart of this study. Local ethics committee approved the usage and publication of these data. Written informed consent was not considered necessary by the ethics committee because of the blinded data and retrospective design. (Approval letter No. 2018BJYYEC-196-02).

Baseline characteristics included age, gender, body mass index (BMI), American Society of Anaesthesiologists (ASA) classification, preoperative obstructive jaundice. Age-adjusted Charlson comorbidity index (aCCl) was used to assess the comorbidities [8]. In China, anaemia was defined according to both the level of haemoglobin and gender. Haemoglobin less than $12 \mathrm{~g} / \mathrm{L}$ in male and $11 \mathrm{~g} / \mathrm{L}$ in female were defined as anaemia [9]. All patients recruited received no preoperative blood transfusion and supplement therapy.

Several nutritional variables such as albumin, nutritional risk and malnutrition were included. The nutritional risk was defined by the tool named nutritional risk screening 2002 (NRS2002) [10] and malnutrition was defined by the global leadership initiative malnutrition (GLIM) diagnosis criteria [11].

\section{Intraoperative and Postoperative Data}

The operation method of open pancreatoduodenectomy was unified in our two institutes due to long term cooperation. Intraoperative data included duration of the procedure, volumes of blood loss, intraoperative red blood cell, and fluid infusion. The malignant and benign pathologies were also recorded, especially pancreatic ductal adenocarcinoma (PDAC).

Complications were recorded totally according to the Claviene-Dindo (CD) classification system (Minor: I-II; Major: III-V) [12]. We defined that all postoperative outcomes recorded were happened until discharge. Postoperative pancreatic fistula (POPF) was defined and graded according to the 2016 International Study Group of Pancreatic Surgery (ISGPS) classification and clinically relevant POPF (CRPOPF) contained both grade $B$ and $C$ [13]. Nonfistulous complications like postpancreatectomy haemorrhage (PPH), delayed gastric emptying (DGE), biliary fistula, abdominal infection, cardiac and cerebrovascular events were also included and ISGPS definitions and classifications of PPH and DGE were followed $[14,15]$.

In-hospital reoperation rate, postoperative length of stay (LOS), 30-day readmission rate, perioperative mortality and total hospital costs were recorded. Total hospital costs only contained the direct cost on the hospitalization bill including fees for operation, drugs and medical equipment, nursing care and other medical service such as consultation.

\section{Propensity Score Matching (PSM)}

Propensity score matching was applied to achieve a balance between two groups. We selected variables those were significantly different between two groups in the original data analysis by groups comparison and logistic analysis, including age, albumin, Charlson comorbidity index and preoperative obstructive jaundice to 
generate the propensity score and binary logistic regression with selected variables was used to generate continuous propensity scores from 0 to 1 . Patients were matched by a matching ratio $1: 1$ based on the propensity score with a standard caliper width of $0.02[16]$.

\section{Statistical Analysis}

The data were collected and checked by two staffs to ensure accuracy at the two institutions. IBM SPSS Statistics (Ver. 26.0, IBM Corp., Armonk, NY, USA) was used to do the statistical analysis by professional statisticians. Categorical data were analysed using the chi-square test or Fisher exact test. Continuous data was tested by Student's unpaired t test. Charlson comorbidity index was shown by median and interquartile range (IQR), and analysed using Mann-Whitney $U$ test. Multivariable logistic regression analysis was used to evaluate the relationship between risk factors and anaemia and postoperative severe complications respectively, which was expressed as an odds ratio (OR) with $95 \%$ confidence intervals. We determined the risk factors by referring to several published articles and what we had in our database, including age, sex, comorbidities, nutrition related variables, pathology and some intraoperative items [7,17]. We did the logistic analysis of the risk factors of anaemia in total cohort in order to reduce the error caused by missing cases and we did the analysis of the risk factors of complications in the paired cohort in order to prevent the influence of bias. $P$ values of less than 0.05 were considered statistically significant.

\section{Results}

\section{Basal data of all patients}

Totally, 517 consecutive patients were included with the main age $62.0 \pm 11.6$ years old (range: $16-88$ years). The male: female ratio was 1.5:1 (307:210). 148 cases (28.6\%) were diagnosed as anaemia at admission, and no case received preoperative blood transfusion or anti-anaemia therapy. 151 (29.2\%) cases had a history of long-term drinking and 171 (33.1\%) were heavy smokers. The median and interquartile range of aCCl were 4.0 $(3.0,5.0)$. 301(58.2\%) patients had obstructive jaundice. Referring to nutrition status, the main BMI was $23.5 \pm$ $3.3 \mathrm{~kg} / \mathrm{m}^{2}$. The main plasma albumin concentration was $38.5 \pm 6.3 \mathrm{~g} / \mathrm{L} .319(61.7 \%)$ cases were at nutritional risk by NRS2002 and 132 (25.5\%) cases were malnourished determined by GLIM. According to postoperative pathologic results, the malignance took over $77.6 \%$ and $151(29.2 \%)$ cases were pancreatic ductal adenocarcinoma.

\section{Logistic analysis of risk factors of preoperative anaemia}

Figure 2 and 3 showed the results of univariate and multivariate analysis in all patients. We aimed to find out the risk factor of preoperative anaemia. After multivariate analysis, preoperative obstructive jaundice $[\mathrm{OR}=$ $1.813,95 \% \mathrm{Cl}(1.206-2.725), \mathrm{p}=0.004]$ and pathologic diagnosis of pancreatic ductal adenocarcinoma [OR $=$ $1.861,95 \% \mathrm{Cl}(1.178-2.939), p=0.008]$ were proved to be two risk factors of preoperative anaemia with statistical significance.

\section{Logistic analysis of risk factors of preoperative anaemia}

Table 1 showed the comparison of basal data between anaemia and normal groups before and after PSM. Before PSM, we could see that patients who were older $(63.7$ vs. $61.8, p=0.033)$ or with more severe 
comorbidity assessed by aCCI [median 4.0 (IQR 1.0) vs. 4.0 (IQR 2.0), $p=0.013$ ], especially preoperative obstructive jaundice $(68.2 \%$ vs. $54.2 \%, p=0.003)$ were more likely to develop anaemia. And lower albumin (mean $35.3 \pm 5.9$ vs. $39.8 \pm 6.0, p=0.000$ ) maybe simultaneously occurred due to nutritional factors or chronic consumption caused by disease. After PSM all baseline variables were balanced. 
Table 1

Basal data comparison between anemia and no anemia groups

\begin{tabular}{|c|c|c|c|c|c|c|}
\hline \multirow[t]{2}{*}{ Variable } & \multicolumn{2}{|l|}{ Before PSM } & \multirow[t]{2}{*}{$P$} & \multicolumn{2}{|l|}{ After PSM } & \multirow[t]{2}{*}{$P$} \\
\hline & $\begin{array}{l}\text { Anaemia group } \\
(n=148)\end{array}$ & $\begin{array}{l}\text { No anaemia } \\
\text { group }(n=369)\end{array}$ & & $\begin{array}{l}\text { Anaemia group } \\
(n=126)\end{array}$ & $\begin{array}{l}\text { No anaemia } \\
\text { group }(n=126)\end{array}$ & \\
\hline $\begin{array}{l}\text { Age, mean } \\
\text { (SD), y }\end{array}$ & $63.7(10.4)$ & $61.8(11.9)$ & 0.033 & $63.0(10.5)$ & $63.8(10.2)$ & 0.555 \\
\hline $\begin{array}{l}\text { Sex, male, } \mathrm{n} \\
(\%)\end{array}$ & $96(64.9)$ & $211(57.2)$ & 0.108 & $51(40.5)$ & $41(32.5)$ & 0.191 \\
\hline $\begin{array}{l}\text { ASA }(1 / I I / I I I), \\
n(\%)\end{array}$ & $\begin{array}{l}8 / 111 / 29 \\
(5.4 / 75.0 / 19.6)\end{array}$ & $\begin{array}{l}34 / 292 / 43 \\
(9.2 / 79.1 / 11.7)\end{array}$ & 0.074 & $\begin{array}{l}7 / 94 / 25 \\
(5.5 / 74.6 / 19.8)\end{array}$ & $\begin{array}{l}10 / 98 / 18 \\
(7.9 / 77.8 / 14.3)\end{array}$ & 0.371 \\
\hline $\begin{array}{l}\text { Charlson } \\
\text { comorbidity } \\
\text { index, } \\
\text { median } \\
\text { (IQR) }\end{array}$ & $4.0(1.0)$ & $4.0(2.0)$ & 0.013 & $2.0(2.0)$ & $4.0(1.0)$ & 0.776 \\
\hline $\begin{array}{l}\text { Preoperative } \\
\text { obstructive } \\
\text { jaundice, } \mathrm{n} \\
(\%)\end{array}$ & $101(68.2)$ & $200(54.2)$ & 0.003 & $83(65.9)$ & 89 (70.6) & 0.417 \\
\hline \multicolumn{7}{|l|}{$\begin{array}{l}\text { Nutrition } \\
\text { status }\end{array}$} \\
\hline $\begin{array}{l}\text { BMI, mean } \\
\text { (SD), } \mathrm{kg} / \mathrm{m}^{2}\end{array}$ & $23.2(3.8)$ & $23.7(3.0)$ & 0.131 & $23.2(3.9)$ & $23.9(3.2)$ & 0.146 \\
\hline $\begin{array}{l}\text { Albumin, } \\
\text { mean (SD), } \\
\text { g/L }\end{array}$ & $35.3(5.9)$ & $39.8(6.0)$ & 0.000 & 36.5 (5.5) & 36.7 (5.8) & 0.693 \\
\hline $\begin{array}{l}\text { NRS2002- } \\
\text { define } \\
\text { nutritional } \\
\text { risk }\end{array}$ & 91 (61.5) & 228 (61.8) & 0.949 & 75 (59.5) & $76(60.3)$ & 0.898 \\
\hline $\begin{array}{l}\text { GLIM- } \\
\text { defined } \\
\text { malnutrition }\end{array}$ & 38 (25.7) & $94(25.5)$ & 0.962 & $29(23.0)$ & $34(27.0)$ & 0.467 \\
\hline $\begin{array}{l}\text { Malignant } \\
\text { pathology, n } \\
(\%)\end{array}$ & 117 (79.1) & $284(77.0)$ & 0.053 & $113(89.7)$ & $102(81.0)$ & 0.050 \\
\hline \multicolumn{7}{|c|}{$\begin{array}{l}\text { ASA: American Society of Anaesthesia; BMI: body mass index; NRS: nutritional risk screening; GLIM: } \\
\text { global leadership initiative malnutrition; }\end{array}$} \\
\hline SD: standa & ition; IQR: in & artile range & & & & \\
\hline
\end{tabular}

Outcomes comparison before and after PSM 
Table 2 showed the comparison of outcome parameters between anaemia and normal groups before and after PSM. For intraoperative data, blood loss and RBC transfusion were reported to be the risk factors of poor outcomes [5] and might be the bias in this study. After matching, the differences were balanced and the bias were declined. Referring to postoperative data, we could see that the differences of several variables remained statistically obvious after PSM including the rate of severe postoperative complications $(43.7 \%$ vs. $27.0 \%, p=$ 0.006), especially the rate of CR-POPF and PPH and the difference of total hospital costs. The difference of prevalence of cardiac and cerebrovascular complications between two groups became significant after matching $(4.0 \%$ vs. $0.0 \%, p=0.024)$. 
Table 2

Complication and outcome comparison between anemia and no anemia groups

\begin{tabular}{|c|c|c|c|c|c|c|}
\hline \multirow[t]{2}{*}{ Variable } & \multicolumn{2}{|l|}{ Before PSM } & \multirow[t]{2}{*}{$P$} & \multicolumn{2}{|l|}{ After PSM } & \multirow[t]{2}{*}{$P$} \\
\hline & $\begin{array}{l}\text { Anaemia } \\
\text { group }(\mathrm{n}= \\
\text { 148) }\end{array}$ & $\begin{array}{l}\text { No anaemia } \\
\text { group }(n= \\
369)\end{array}$ & & $\begin{array}{l}\text { Anaemia } \\
\text { group }(n= \\
126)\end{array}$ & $\begin{array}{l}\text { No anaemia } \\
\text { group }(n= \\
126)\end{array}$ & \\
\hline \multicolumn{7}{|l|}{ Intraoperative } \\
\hline $\begin{array}{l}\text { Operation duration, } \\
\text { mean (SD), min }\end{array}$ & $\begin{array}{l}404.2 \\
(134.6)\end{array}$ & $360.0(108.8)$ & 0.001 & $\begin{array}{l}399.1 \\
(128.1)\end{array}$ & $\begin{array}{l}368.6 \\
(111.8)\end{array}$ & 0.045 \\
\hline $\begin{array}{l}\text { Blood loss, median } \\
\text { (IQR), ml }\end{array}$ & $\begin{array}{l}500.0 \\
(600.0)\end{array}$ & $400.0(400.0)$ & 0.000 & $\begin{array}{l}500.0 \\
(600.0)\end{array}$ & $\begin{array}{l}500.0 \\
(800.0)\end{array}$ & 0.655 \\
\hline $\begin{array}{l}\text { Fluid infusion, mean } \\
\text { (SD), ml }\end{array}$ & $\begin{array}{l}4320.0 \\
(2443.2)\end{array}$ & $\begin{array}{l}3937.4 \\
(2458.2)\end{array}$ & 0.111 & $\begin{array}{l}4272.9 \\
(2454.0)\end{array}$ & $\begin{array}{l}3944.1 \\
(1529.3)\end{array}$ & 0.203 \\
\hline $\begin{array}{l}\text { RBC transfusion, } \mathrm{n} \\
(\%)\end{array}$ & $86(58.1)$ & 118 (32.0) & 0.000 & $72(57.1)$ & $77(61.1)$ & 0.522 \\
\hline $\begin{array}{l}\text { RBC transfusion } \\
\text { volume, median (IQR), } \\
\text { ml }\end{array}$ & $\begin{array}{l}340.0 \\
(680.0)\end{array}$ & $0.0(340.0)$ & 0.000 & $\begin{array}{l}340.0 \\
(600.0)\end{array}$ & $\begin{array}{l}340.0 \\
(680.0)\end{array}$ & 0.203 \\
\hline \multicolumn{7}{|l|}{ Postoperative } \\
\hline $\begin{array}{l}\text { CD III-V } \\
\text { complications, n (\%) }\end{array}$ & $65(43.9)$ & $111(30.1)$ & 0.003 & $55(43.7)$ & $34(27.0)$ & 0.006 \\
\hline CR-POPF, n (\%) & $45(30.4)$ & $60(16.3)$ & 0.000 & $39(31.0))$ & $20(15.9)$ & 0.005 \\
\hline PPH Grade B/C, n (\%) & $27(18.2)$ & $40(10.8)$ & 0.023 & $25(19.8)$ & $16(12.7)$ & 0.125 \\
\hline Biliary fistula, n (\%) & $18(12.2)$ & $29(7.9)$ & 0.124 & $14(11.1)$ & $10(7.9)$ & 0.391 \\
\hline $\begin{array}{l}\text { Abdominal infection, } \\
\mathrm{n}(\%)\end{array}$ & $26(17.6)$ & $30(8.1)$ & 0.002 & $21(16.7)$ & $11(8.7)$ & 0.058 \\
\hline DGE Grade B/C, n (\%) & $25(16.9)$ & $53(14.4)$ & 0.468 & $22(17.5)$ & $19(15.1)$ & 0.609 \\
\hline $\begin{array}{l}\text { Cardiac and } \\
\text { cerebrovascular } \\
\text { events, } \mathrm{n}(\%)\end{array}$ & $5(3.4)$ & $4(1.1)$ & 0.071 & $5(4.0)$ & $0(0.0)$ & 0.024 \\
\hline Reoperation, n (\%) & $9(6.1)$ & $17(4.6)$ & 0.488 & $8(6.3)$ & $6(4.8)$ & 0.582 \\
\hline \multicolumn{7}{|l|}{ Outcomes } \\
\hline $\begin{array}{l}\text { Postoperative LOS, } \\
\text { mean (SD), day }\end{array}$ & $27.3(18.3)$ & $25.6(18.2)$ & 0.324 & $27.0(18.2)$ & $24.9(17.3)$ & 0.346 \\
\hline $\begin{array}{l}\text { 30-day readmission } \\
\text { rate, } \mathrm{n}(\%)\end{array}$ & $3(2.0)$ & $5(1.4)$ & 0.576 & $3(2.4)$ & $2(1.6)$ & 0.651 \\
\hline \multicolumn{7}{|c|}{$\begin{array}{l}\text { RBC: red blood cell; CD: Claviene-Dindo; CR-POPF: clinically relevant -postoperative pancreatic fistula; PPH: } \\
\text { Postopancreatectomy haemorrhage; }\end{array}$} \\
\hline
\end{tabular}




\begin{tabular}{|c|c|c|c|c|c|c|}
\hline \multirow[t]{2}{*}{ Variable } & \multicolumn{2}{|c|}{ Before PSM } & \multirow[t]{2}{*}{$P$} & \multicolumn{2}{|l|}{ After PSM } & \multirow[t]{2}{*}{$P$} \\
\hline & $\begin{array}{l}\text { Anaemia } \\
\text { group }(n= \\
148)\end{array}$ & $\begin{array}{l}\text { No anaemia } \\
\text { group }(n= \\
369)\end{array}$ & & $\begin{array}{l}\text { Anaemia } \\
\text { group }(n= \\
126)\end{array}$ & $\begin{array}{l}\text { No anaemia } \\
\text { group }(n= \\
126)\end{array}$ & \\
\hline $\begin{array}{l}\text { Perioperative } \\
\text { mortality, } \mathrm{n}(\%)\end{array}$ & $8(5.4)$ & $7(1.9)$ & 0.042 & $7(5.6)$ & $1(0.8)$ & 0.066 \\
\hline $\begin{array}{l}\text { Total hospital costs, } \\
\text { mean (SD), USD }\end{array}$ & $\begin{array}{l}27116.8 \\
(20853.6)\end{array}$ & $\begin{array}{l}20335.9 \\
(10460.9)\end{array}$ & 0.000 & $\begin{array}{l}26958.2 \\
(21671.9)\end{array}$ & $\begin{array}{l}20987.7 \\
(10237.9)\end{array}$ & 0.013 \\
\hline \multicolumn{7}{|c|}{$\begin{array}{l}\text { RBC: red blood cell; CD: Claviene-Dindo; CR-POPF: clinically relevant -postoperative pancreatic fistula; PPH: } \\
\text { Postopancreatectomy haemorrhage; }\end{array}$} \\
\hline
\end{tabular}

\section{Logistic analysis of risk factors of preoperative anaemia}

Figure 4 and 5 showed the univariate and multivariate analysis of the risk factors of severe postoperative complications in patients after PSM. Preoperative anaemia [OR 2.593, 95\% $\mathrm{Cl}(1.481-5.541), \mathrm{P}=0.001$ ] and malignant pathology [OR $4.266,95 \% \mathrm{Cl}(1.597-11.395), \mathrm{P}=0.004$ ] were proved to be predictors of postoperative severe complications.

\section{Discussion}

Pancreatoduodenectomy is one of the major abdominal operations associating with high postoperative mortality and morbidity. There are many risk factors throughout the whole perioperative procedure which may lead to systematic inflammation, metabolic and nutritional disorders including anaemia [18]. Preoperative anaemia in pancreatic surgery was a prevalent condition accounting for $28.6 \%$ in this study, which is similar with the prevalence from other large observational studies in the field of major abdominal surgery. Many factors may result in preoperative anaemia such as age, gender, comorbidities and pathology [19]. All these factors would affect nutrition status because of a combination of malnourishment, malabsorption, chronic gastrointestinal haemorrhage, or the consumption caused by malignant lesions, especially in the elderly [20, 21]. So nutrition-related types of anaemia like iron deficiency anaemia were proved to be the most common in surgical patients [2, 22]. In this study, we proved almost the same risk factors by analysing data before PSM. Patients with anaemia were older, with higher Charlson comorbidity index and prevalence of obstructive jaundice. Meanwhile, patients suffering from PDAC were prone to anaemia.

We also found that aneamic patients had lower albumin, but we treated them as co-existing disorders caused by pancreatic diseases and nutritional changes. So we didn't put it into the logistic analysis. Not like albumin, traditional nutrition screening and assessment tools were not sensitive enough to indicate the existence of anaemia in this study, maybe because the items in these two tools contained only phenotype and etiologic parameters but not the items reflecting internal environment. Recently, the American Society for Enhanced Recovery and Perioperative Quality Initiative Joint developed a new tool named perioperative nutrition screen (PONS) which based on a patient's BMI, recent changes in weight, recent decrease in dietary intake, and preoperative albumin level[23]. There is no relative data of PONS in our database and we hope this new tool 
be validated soon and whether anaemia can be a part of nutrition evaluation needs more studies and evidence.

Blood transfusion was thought to be a double-edged sword of pancreatic surgeons, which might cure anaemia but also bring worse survival in patients with periampullary cancer[24]. Meanwhile, preoperative anaemia may increase the rate of perioperative blood transfusion [5]. In this study, we found that both the proportion of intraoperative transfusion and the transfusion volume were significantly higher in anaemia group before PSM. On the other hand, blood transfusion and preoperative anaemia were co-existing risk factors, but there is not agreement on the relative contribution of each of them so they may become bias to each other when we did the logistic analysis[25, 26]. So after PSM, we could see from Table 2 that the RBC transfusion rate and volume were balanced between two groups, which means we reduced the bias to the utmost in order to make our results reliable.

Referring to outcomes, two aspects were mentioned in this study: intraoperative and postoperative. For intraoperative variables, the patients in anaemia group had longer operation time and more blood loss, which was the same with the results of recent study [27]. Blood loss was balanced after PSM to reduce the interaction with anaemia and transfusion. For postoperative outcomes, many studies have proved the association between preoperative anaemia and postoperative mortality, morbidity and prolonged length of hospital stay in the field of elective major surgery, but the actual role that it plays in pancreatic surgery is still unclear. In our study, we found that the prevalence of severe postoperative complications were higher in the anaemia groups after PSM, especially CR-POPFs and cardiac and cerebrovascular events. Anaemia may lead to changes of blood composition and result in pathophysiologic changes which influence circulation. In a recent retrospective study, the authors found that preoperative anaemia was independently associated with myocardial injury after noncardiac surgery[28] and in some studies in cardiac surgery, the association between preoperative anaemia and postoperative stroke was reported [29].

Since preoperative anaemia is associated with increased postoperative complications and worse patient outcomes after surgery, more surgeons agreed with intervention should be incorporated into routine care before major operation [30]. However, how to treat preoperative anaemia was still controversial to a certain extent [6]. International guidelines support the use of intravenous iron to correct anaemia in patients before surgery, but a recent RCT showed no benefit from giving intravenous iron before the operation [31]. So more studies are needed to make a appropriate strategy towards preoperative anaemia.

There are several limitations that may impact the analysis. First, this is a retrospective study and the sample size is relatively small. Second, data were limited to the immediate postoperative period and cannot reflect the influence on long term outcomes especially survival.

\section{Conclusion}

The prevalence of preoperative anaemia is high in pancreatic surgery. It is a predictor of cacoethic postoperative outcomes following open pancreatoduodenectomy such as severe postoperative complications, cardiac and cerebrovascular events and higher hospital cost. It needs timely identified and treated before surgery and more high-grade evidences are needed in the future. 


\section{Abbreviations}

PSM: propensity score matching; BMI: body mass index; ASA: American Society of Anaesthesiologists; aCCl: Age-adjusted Charlson comorbidity index; NRS: nutritional risk screening; GLIM: global leadership initiative malnutrition; $C D$ : Claviene-Dindo; POPF: postoperative pancreatic fistula; CR-POPF: clinically relevant postoperative pancreatic fistula; PPH: postpancreatectomy haemorrhage; DGE: delayed gastric emptying; ISGPS: International Study Group of Pancreatic Surgery; LOS: length of stay; PSM: propensity score matching; IQR: interquartile range; OR: odds ratio; PONS: perioperative nutrition screen; SD: standard deviation; USD: United State dollar; RBC: red blood cell; RCT: randomized control trial; PDAC: pancreatic ductal adenocarcinoma

\section{Declarations}

\section{Ethics approval and consent to participate}

This study was approved by the Ethics Committee of the Beijing Hospital (Approval letter No. 2018BJYYEC196-02). Written informed consent was not considered necessary by the ethics committee because of the blinded data and retrospective design.

\section{Consent for publication}

Not applicable.

\section{Availability of data and materials}

The retrospective data used to support the findings of this study are restricted by the ethics boards of both hospitals of the corresponding authors in order to protect patient privacy. Some of the data may be available from the corresponding author (Jing-Hai Song) upon request.

\section{Competing interests}

No benefits in any form have been received or will be received from a commercial party related directly or indirectly to the subject of this article. The authors declare no conflict of interest.

\section{Funding}

This work was supported by the Capital Characteristic Clinical Project Supported by Beijing Municipal Science \& Technology Commission (No. Z181100001718216) and Beijing Hospital Nova Project (No.BJ-2020-082).

\section{Authors' contributions}

(I)Conception and design: JH Song, JM Wei, YM Yang, JY Xu; (II) Administrative support: YM Yang, JH Song; (III) Provision of study materials or patients: JY Xu, XD Tian; (IV) Collection and assembly of data: JY Xu, XD Tian; (V) Data analysis and interpretation: JY Xu, XD Tian; (VI) Manuscript writing: All authors; (VI) Final approval of manuscript: All authors. 
Not applicable.

\section{References}

1. Fowler AJ, Ahmad T, Phull MK, Allard S, Gillies MA, Pearse RM. Meta-analysis of the association between preoperative anaemia and mortality after surgery. Br J Surg. 2015;102(11):1314-24.

2. Muñoz M, Laso-Morales MJ, Gómez-Ramírez S, Cadellas M, Núñez-Matas MJ, García-Erce JA. Preoperative haemoglobin levels and iron status in a large multicentre cohort of patients undergoing major elective surgery. Anaesthesia. 2017;72(7):826-34.

3. Musallam KM, Tamim HM, Richards T, Spahn DR, Rosendaal FR, Habbal A, et al. Preoperative anaemia and postoperative outcomes in non-cardiac surgery: a retrospective cohort study. Lancet. 2011;378(9800):1396-407.

4. Baron DM, Hochrieser $H$, Posch M, Metnitz B, Rhodes A, Moreno RP, et al. Preoperative anaemia is associated with poor clinical outcome in non-cardiac surgery patients. Br J Anaesth. 2014;113(3):41623.

5. Delaney M, Wendel S, Bercovitz RS, Cid J, Cohn C, Dunbar NM, et al. Transfusion reactions: prevention, diagnosis, and treatment. Lancet. 2016;388(10061):2825-36.

6. Abbott TEF, Gillies MA. The PREVENNT randomised, double-blind, controlled trial of preoperative intravenous iron to treat anaemia before major abdominal surgery: an independent discussion. $\mathrm{Br} \mathrm{J}$ Anaesth. 2021;126(1):157-62.

7. Xu J, Zhang A, Tang B, Tian X, Ma Y, Song J, et al. Modification of a new subclassification of Grade B postoperative pancreatic fistula: A bicenter retrospective cohort study. J Hepatobiliary Pancreat Sci. 2020 Jun 7. doi:10.1002/jhbp.780.

8. Koppie TM, Serio AM, Vickers AJ, Vora K, Dalbagni G, Donat SM, et al. Age-adjusted Charlson comorbidity score is associated with treatment decisions and clinical outcomes for patients undergoing radical cystectomy for bladder cancer. Cancer. 2008;112(11):2384-92.

9. Lu ZY, Zhong NS. Anemia. Internal Medicine. 2nd ed. Beijing: People's Medical Publishing House; 2008. In Chinese.

10. Xu JY, Zhang XN, Jiang ZM, Jie B, Wang Y, Li W, et al. Nutritional support therapy after GLIM criteria may neglect the benefit of reducing infection complications compared with NRS2002: Reanalysis of a cohort study. Nutrition. 2020 Nov-Dec;79-80:110802.

11. Xu JY, Zhu MW, Zhang H, Li L, Tang PX, Chen W, et al. A cross-sectional study of GLIM-defined malnutrition based on new validated calf circumference cut-off values and different screening tools in hospitalised patients over 70 years old. J Nutr Health Aging. 2020;24(8):832-8.

12. Dindo D, Demartines N, Clavien PA. Classification of surgical complications: a new proposal with evaluation in a cohort of 6336 patients and results of a survey. Ann Surg. 2004;240:205-13.

13. Bassi C, Marchegiani G, Dervenis C, Sarr M, Abu Hilal M, Adham M, et al. The 2016 update of the International Study Group (ISGPS) definition and grading of postoperative pancreatic fistula: 11 Years 
After. Surgery. 2017;161(3):584-91.

14. Panwar R, Pal S. The International Study Group of Pancreatic Surgery definition of delayed gastric emptying and the effects of various surgical modifications on the occurrence of delayed gastric emptying after pancreatoduodenectomy. Hepatobiliary Pancreat Dis Int. 2017;16(4):353-63.

15. Wente MN, Veit JA, Bassi C, Dervenis C, Fingerhut A, Gouma DJ, et al. Postpancreatectomy hemorrhage (PPH): an International Study Group of Pancreatic Surgery (ISGPS) definition. Surgery. 2007;142(1):20-5.

16. AustinPC. Optimal caliper widths for propensity-score matching when estimating differences in means and differences in proportions in observational studies. Pharm Stat. 2011;10:150-61.

17. Xu JY, Tian XD, Song JH, Chen J, Yang YM, Wei JM. Preoperative Nutrition Support May Reduce the Prevalence of Postoperative Pancreatic Fistula after Open Pancreaticoduodenectomy in Patients with High Nutritional Risk Determined by NRS2002. Biomed Res Int. 2021 May 20;2021:6691966. doi: $10.1155 / 2021 / 6691966$.

18. Xu J, Wei J. Current situation, consensus and controversy of perioperative nutrition management in pancreatic surgery: A narrative review. Journal of Pancreatology. 2021;4(1):37-44.

19. Shander A, Knight K, Thurer R, Adamson J, Spence R. Prevalence and outcomes of anemia in surgery: a systematic review of the literature. Am J Med. 2004 Apr;5(116 Suppl 7A):58S-69S.

20. Busti F, Campostrini N, Martinelli N, Girelli D. Iron deficiency in the elderly population, revisited in the hepcidin era. Front Pharmacol. 2014;5:83.

21. Goodnough LT. Iron deficiency syndromes and iron-restricted erythropoiesis (CME). Transfusion. 2012;52(7):1584-92.

22. Hong FS, Sieradzki N, Pollock C, Nasra F, Mo A, Willcox A, et al. Prevalence and causes of preoperative anaemia in elective major surgery patients. Intern Med J. 2017;47(12):1400-4.

23. Wischmeyer PE, Carli F, Evans DC, Guilbert S, Kozar R, Pryor A, et al. American Society for Enhanced Recovery and Perioperative Quality Initiative Joint Consensus Statement on Nutrition Screening and Therapy Within a Surgical Enhanced Recovery Pathway. Anesth Analg. 2018;126(6):1883-95.

24. Sutton JM, Kooby DA, Wilson GC, Squires MH 3rd, Hanseman DJ, Maithel SK, et al. Perioperative blood transfusion is associated with decreased survival in patients undergoing pancreaticoduodenectomy for pancreatic adenocarcinoma: a multi-institutional study. J Gastrointest Surg. 2014;18(9):1575-87.

25. Kneuertz PJ, Patel SH, Chu CK, Maithel SK, Sarmiento JM, Delman KA, et al. Effects of perioperative red blood cell transfusion on disease recurrence and survival after pancreaticoduodenectomy for ductal adenocarcinoma. Ann Surg Oncol. 2011;18(5):1327-34.

26. Muñoz M, Gómez-Ramírez S, Campos A, Ruiz J, Liumbruno GM. Pre-operative anaemia: prevalence, consequences and approaches to management. Blood Transfus. 2015;13(3):370-9.

27. Park HM, Park SJ, Shim JR, Lee EC, Lee SD, Han SS, et al. Perioperative transfusion in pancreatoduodenectomy: The double-edged sword of pancreatic surgeons. Medicine. 2017;96(49):e9019.

28. Kwon JH, Park J, Lee SH, Lee JH, Min JJ, Kim J, et al. Pre-operative anaemia and myocardial injury after noncardiac surgery: A retrospective study. Eur J Anaesthesiol. 2021;38(6):582-90.

29. Jabagi H, Boodhwani M, Tran DT, Sun L, Wells G, Rubens FD. The Effect of Preoperative Anemia on Patients Undergoing Cardiac Surgery: A Propensity-Matched Analysis. Semin Thorac Cardiovasc Surg. 
2019;31(2):157-63.

30. Hussey P, Onodera Y, Reddy S, Samuelson B, Subramani S, Siddapura Ranganath Y, et al. Need for preoperative anemia management clinics in Japan: initiatives at a university hospital in the USA. J Anesth. 2021 Aug 2. doi:10.1007/s00540-021-02979-9.

31. Richards T, Baikady RR, Clevenger B, Butcher A, Abeysiri S, Chau M, et al. Preoperative intravenous iron for anaemia in elective major open abdominal surgery: the PREVENTT RCT. Health Technol Assess. $2021 ; 25(11): 1-58$.

\section{Figures}




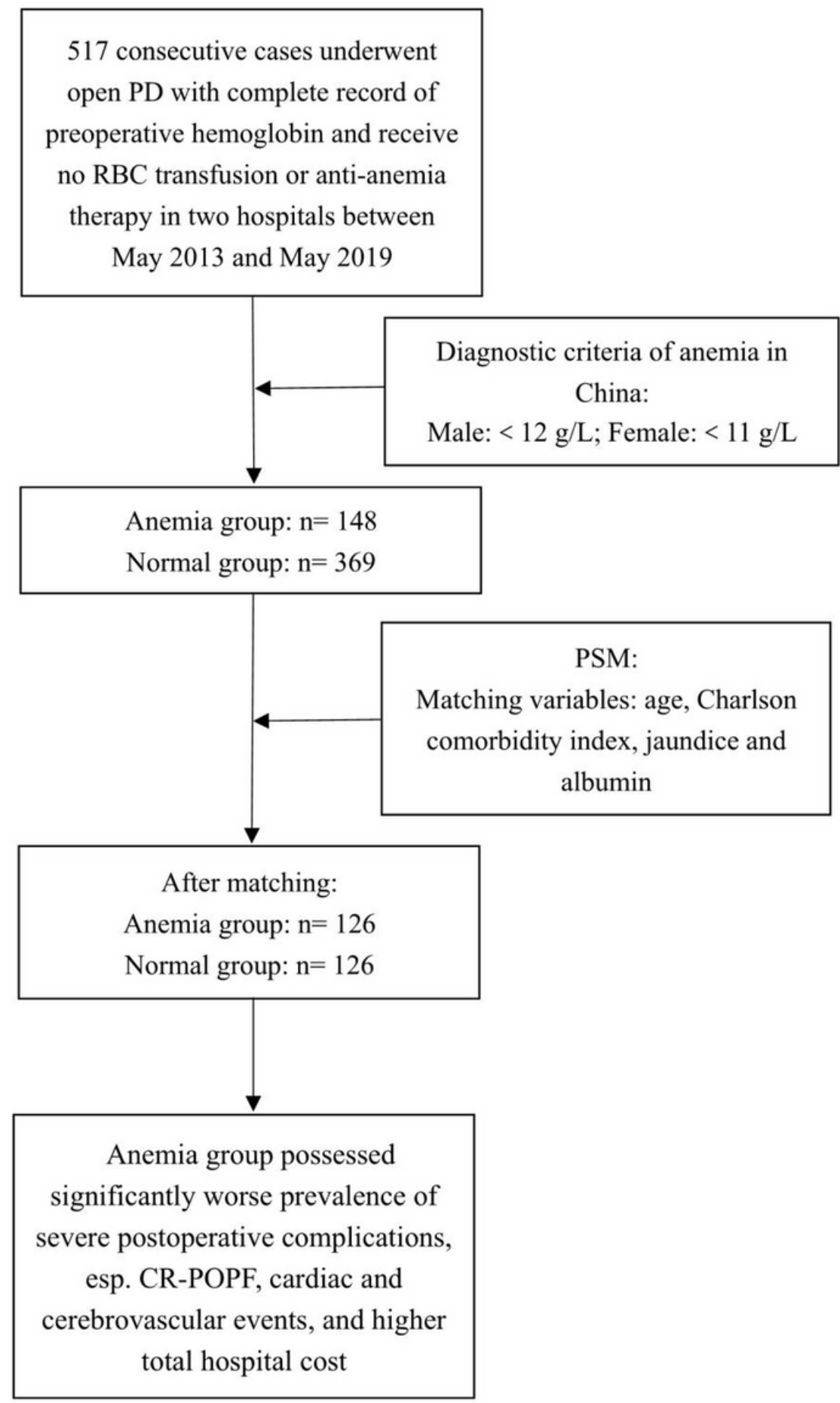

\section{Figure 1}

Flowchart of the study 


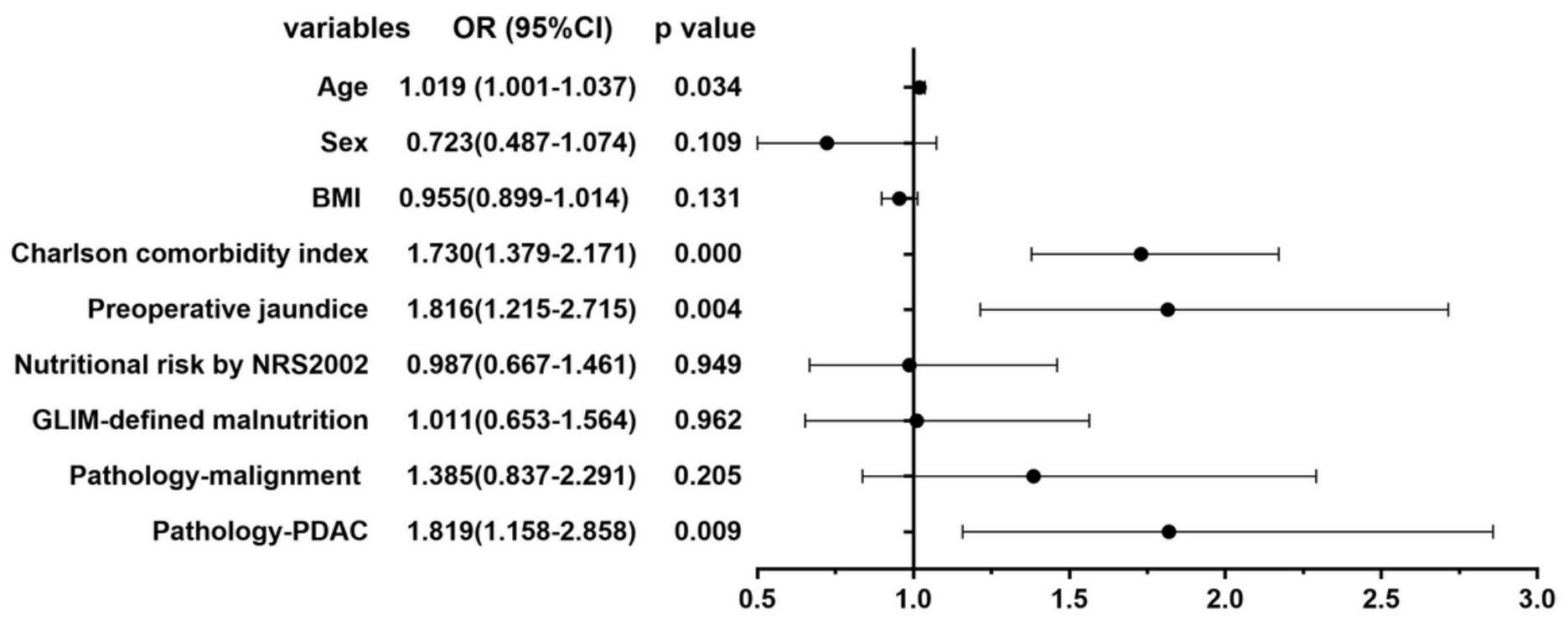

Figure 2

Univariate analysis of the risk factors of preoperative anemia in all patients

variable $\quad \mathrm{OR}(95 \% \mathrm{Cl}) \quad \mathrm{p}$ value

Age $\quad 1.012(0.960-1.066) \quad 0.662$

Charlson comorbidity index $1.078(0.613-1.896) \quad 0.795$

Preoperative jaundice $1.813(1.206-2.725) \quad 0.004$

Pathology-PDAC $\quad 1.861(1.178-2.939) \quad 0.008$

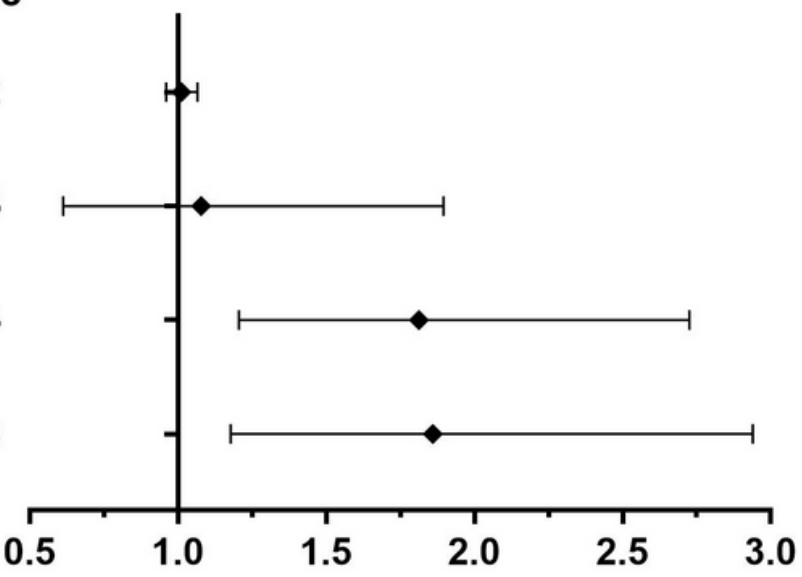

Figure 3

Multivariate analysis of the risk factors of preoperative anemia in all patients 


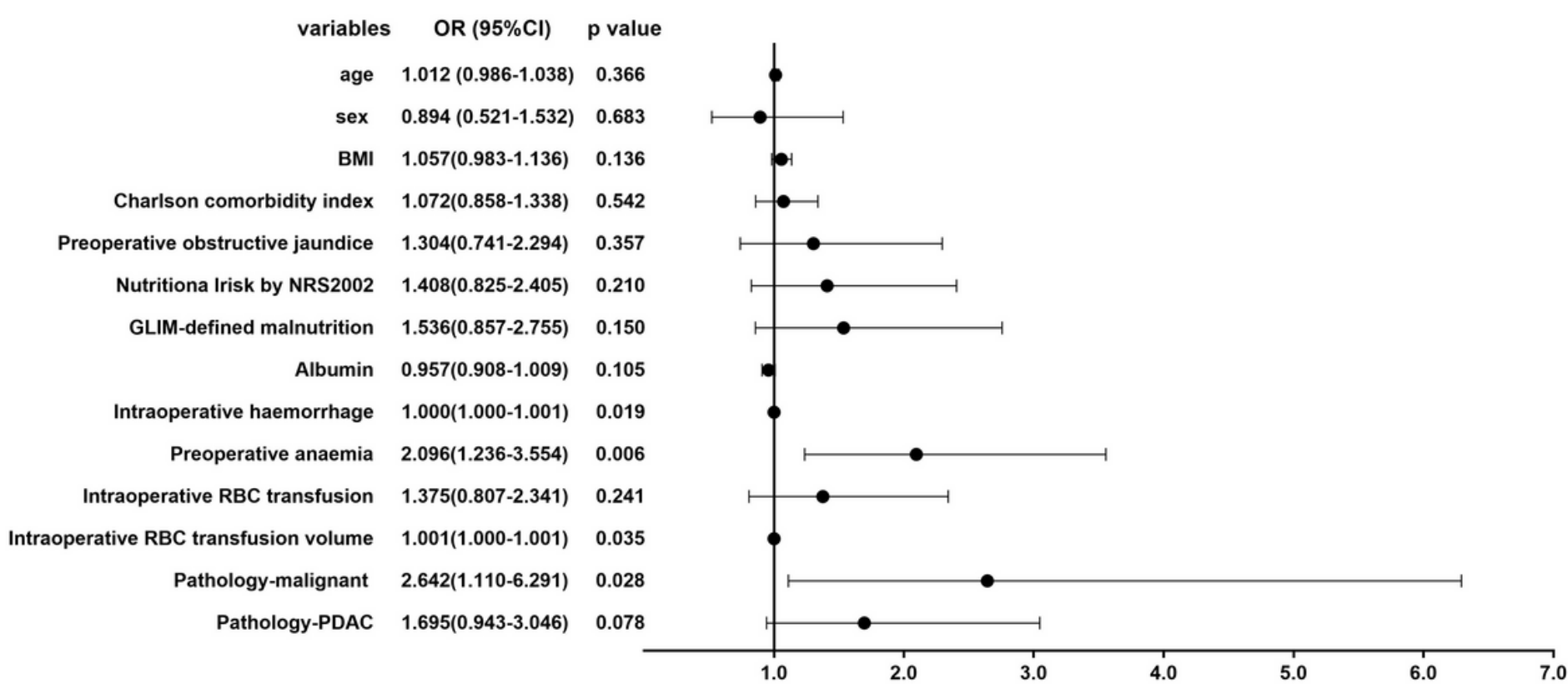

Figure 4

Univariate analysis of the risk factors of severe postoperative complications in patients after PSM

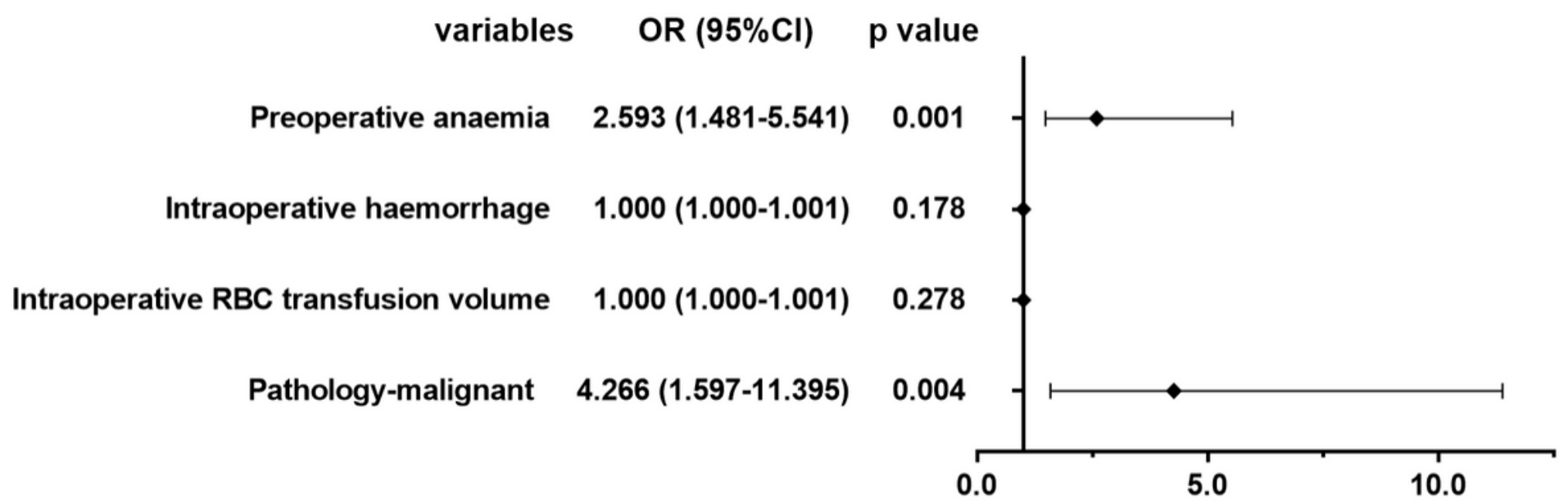

Figure 5

Multivariate analysis of the risk factors of severe postoperative complications in patients after PSM 